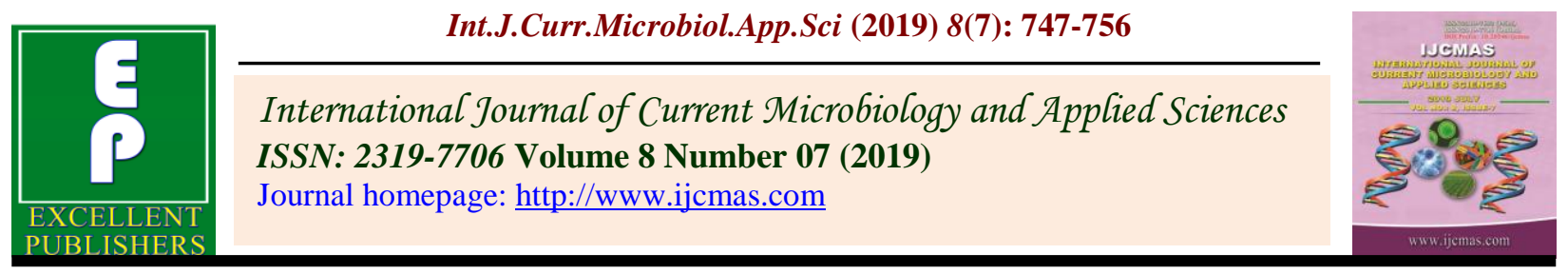

\title{
Detection of Epistasis and Estimation of Additive and Dominance Components of Genetic Variation for Fruit Yield and Horticultural Traits in Okra [Abelmoschus esculentus (L.) Moench]
}

\author{
Akhilesh Singh*, Sonia Sood and V.K. Sood \\ Department of Vegetable Science and Floriculture, College of Agriculture, CSK Himachal \\ Pradesh Krishi Vishvavidyalaya, Palampur (HP)-176 062, India \\ *Corresponding author
}

\begin{tabular}{|l|}
\hline K e y w o r d s \\
$\begin{array}{l}\text { Okra, gene action, } \\
\text { epistasis, triple test } \\
\text { cross analysis, } \\
\text { genetic components }\end{array}$ \\
\hline Article Info \\
\hline $\begin{array}{l}\text { Accepted: } \\
\text { xx June } 2019 \\
\text { Available Online: } \\
\text { xx July } 2019\end{array}$ \\
\hline
\end{tabular}

\section{Introduction}

Okra [Abelmoschus esculentus (L.) Moench $2 \mathrm{n}=130$ ] belongs to the Malvaceae family. The crop was earlier included in the genus Hibiscus, section Abelmoschus of this family. Okra is raised throughout the tropics and warmer parts of temperate regions.
A B S T R A C T

In order to detect gene action and epistatic effects for fruit yield and horticultural traits, 12 fixed lines, three testers and their 36 triple test cross families of okra were used in a randomized complete block design with three replications at the Experimental Farm, Department of Vegetable Science and Floriculture, CSKHPKV, Palampur (H.P.) during summer-rainy season, 2016-2018. Analysis of variance revealed significant differences among treatments. Triple test cross analysis revealed epistatic effects for days to 50 per cent flowering, plant height, harvest duration, fruit yield per plant and mucilage. (i) type epistasis was observed for the traits $v i z$., fruit length, harvest duration, fruit yield per plant, ridges per fruit and mucilage whereas $(\mathrm{j}+\mathrm{l})$ type epistasis for days to 50 per cent flowering, days to first picking, plant height, harvest duration, fruit yield per plant and mucilage. Both additive and non-additive gene actions were significant for days to 50 per cent flowering, first fruit producing node, plant height, harvest duration, fruit yield per plant, ridges per fruit and mucilage. For these traits, selection in segregating generations and hybridization breeding methods could prove to be useful. Higher D than $\mathrm{H}$ for all the traits was showing incomplete dominance except for mucilage. Correlation coefficient (r) between sums and differences of lines were non-significant for most traits except fruit length and harvest duration, suggesting ambidirectional nature of dominant genes between lines. Comparison of the line $\mathrm{x}$ tester and triple test cross approach used in the experiment for the additive and dominance components of genetic variance revealed underestimation of both additive and dominance genetic components in the line $\mathrm{x}$ tester mating design. 
okra to be widely cultivated and propagated in India, which ranks first in the world with an annual production of $60,95,000$ metric tons produced from 5,09,000 hectares area, the average productivity being 11.97 tonnes/ha (Anonymous, 2018). An appreciable quantum of information on inheritance pattern of different traits of okra is available, but still the aforementioned intent holds a future promise as the nature of gene action varies with the experimental material and the environment under study.

Information of the type of gene action involved in the inheritance of traits is helpful in deciding the breeding procedures to be followed for plant improvement and is necessary for efficient utilization of available germplasm in a breeding programme. The choice among several breeding methods depends upon the genetic architecture of the traits being considered (Cockerham, 1961). A number of breeding approaches have been suggested to study genetic architecture of polygenic traits. These approaches have advantages and disadvantages, but a method suitable for a particular situation may not be suitable under other situations. An appropriate biometrical method must have least assumptions and should provide reliable genetic information about the material under investigation. Different biometrical techniques viz., biparental cross (Comstock and Robinson, 1948, 1952), diallel and partial diallel cross (Hayman, 1954) and line $\mathrm{x}$ tester cross (Kempthorne, 1957) have been developed which provide information about additive and dominance genetic variances but fail to produce information about epistasis variance because their procedures are based on certain genetical assumptions including absence of non-allelic interactions (Mather and Vines, 1952; Ospal, 1956; Singh and Singh, 1976). Epistasis must be included in model for the unbiased estimation of genetic components (Mather and Jinks, 1971).
Triple test cross analysis, devised by Kearsey and Jinks (1968), is one of the most efficient designs for investigating the genetic architecture of population. Since, this approach provides not only a precise test for epistasis, but also gives unbiased estimates of additive and dominance genetic components in the absence of epistasis. Furthermore, this method provides a comprehensive description of genetic architecture of the population, irrespective of its gene and genotypic frequencies, mating system and correlated gene distribution. Simultaneously, it gives a satisfactory estimate of additive genetic variance necessary for cross prediction. This estimate is uncorrelated with the dominance variance and has a lower bias even in the presence of epistasis (Singh et al., 1987). Its power in detecting epistasis and flexibility in terms of accommodating large samples from the population are some of its advantages (Pooni et al., 1994; Kearsey and Jinks, 1968; Kearsey and Pooni, 1998).

Henceforth, the present investigation was undertaken to get an insight into the genetic factors underlying expression of fruit yield and horticultural traits in okra.

\section{Materials and Methods}

To evaluate gene action and detecting epistatic effects in okra, 51 diverse plant genetic materials were used in a randomized complete block design with three replications in the Experimental Farm, Department of Vegetable Science and Floriculture, CSKHPKV, Palampur.

Two homozygous parents $\left(\mathrm{P}_{1}\right.$ and $\left.\mathrm{P}_{2}\right)$ unrelated and genetically divergent were crossed in year 2016 to obtain their $\mathrm{F}_{1}\left(\mathrm{P}_{1} \mathrm{X}\right.$ $\mathrm{P}_{2}$ ). In year 2017, these two parents and their $\mathrm{F}_{1}\left(\mathrm{P}_{1} \times \mathrm{P}_{2}\right)$, were used as testers (males) to pollinate 12 diverse lines of okra resulting in 36 triple test cross progenies. These 51 genetic 
materials were evaluated in single rows with $45 \mathrm{~cm}$ row to row and $15 \mathrm{~cm}$ plant to plant spacing in randomized complete block design with three replications in year 2018. Data were recorded from 10 randomly selected competitive plants on fifteen traits viz, days to 50 per cent flowering, days to first picking, first fruit producing node, nodes per plant, internodal length, fruit length, fruit diameter, average fruit weight, plant height, harvest duration, fruits per plant, fruit yield per plant, ridges per fruit, dry matter and mucilage.

Triple test cross analysis (Kearsey and Jinks, 1968; Kearsey and Pooni, 1998) was used to detect epistasis. The presence of epistasis was indicated when the mean squares for the deviations $\left(\bar{L}_{1 i}+\bar{L}_{2 i}-2^{\bar{L}_{3 i}}\right)$ were significantly greater than the error. This analysis is valid regardless of gene frequency, degree of inbreeding and linkage relationships (Pooni et al., 1994).

Additive and dominance components were estimated from the analysis of sums and differences assuming no epistasis. The Expected Mean Squares (EMS) of the sums and differences are as follows:

The expectations for $\delta^{2}$ sum and $\delta^{2}$ difference in the absence of epistasis and linkage is $\frac{1}{8} \mathrm{D}$ and $\frac{1}{8}$ $\mathrm{H}$, respectively as shown by Jinks and Perkins (1970) and Pooni et al., (1994):

$$
\mathrm{D} \hat{=} 8\left(\hat{\delta}^{\hat{2}_{\text {sum }}}\right) \quad \text { and } \quad \mathrm{H}=8\left(\hat{\delta}^{2} \text { difference }\right)
$$

The average degree of dominance was estimated as:

$$
\left.\frac{\mathrm{H}}{(\mathrm{D})}\right)^{1 / 2}
$$

The direction of dominance was determined as the correlation coefficient $\left(r_{s, d}\right)$ of the sums and differences (Mather and Jinks, 1982). Significant positive and negative correlation would indicate a predominant direction of dominance towards decreasing and increasing values of the trait.

Also, line $\times$ tester analysis was carried out as per the method given by Kempthorne (1957) after excluding the $\mathrm{L}_{3 \mathrm{i}}$ families and the $\mathrm{F}_{1}$ tester from which additive and dominance genetic variance was determined.

\section{Results and Discussion}

Considerable genetic variation was observed among treatments for all the traits except fruit diameter (Table 1). Significant differences between parents for most traits except fruit diameter and average fruit weight indicated that parents were different from each other. So with absence of non-allelic interaction, the estimation of additive and dominance genetic components of variance would be unbiased. Analysis of variance for testing of epistasis (Table 2) exhibited significant overall epistasis for days to 50 per cent flowering, plant height, harvest duration, fruit yield per plant and mucilage. Further partitioning of the epistasis revealed that i-type (additive $x$ additive) epistasis was significant for the traits viz., fruit length, harvest duration, fruit yield per plant, ridges per fruit and mucilage whereas $\mathrm{j}+\mathrm{l}$ type (additive $\mathrm{x}$ dominance and dominance $\mathrm{x}$ dominance) epistasis was significant for days to 50 per cent flowering, days to first picking, plant height, harvest duration, fruit yield per plant and mucilage. Epistasis for fruit yield and its components traits has been also reported by several recent studies conducted by Panda and Singh (2000), Tripathi and Arora (2001), Saravanan et al., (2005), Arora and Ghai (2007) and Arora et al., (2007) in okra. These results indicated that epistasis could not be ignored in genetic models. Epistatic components related to a large number of interacting genes, lead to 
inefficient selection. But if the number of interacting genes will be reduced, selection will be efficient relied on the magnitude due to dominance and environmental variances.

The analysis of variance for sums and differences between genotypes (Table 3) was used to detect additive and dominance effects, respectively in the presence of epistasis. Estimates of the sums revealed highly significant additive component for all the traits except nodes per plant and fruits per plant. The predominance of additive component suggested that selection in early segregating generations would be effective for improving these traits.

In the presence of epistasis, estimates of additive component (D) were affected by interactions (additive $\mathrm{x}$ additive and additive $\mathrm{x}$ dominance) in loci (Pooni et al., 1994). The analysis of differences (dominance component) was highly significant for days to 50 per cent flowering, first fruit producing node, plant height, harvest duration, fruit yield per plant, ridges per fruit and mucilage. The dominance variance estimated in the triple test cross is related to the different loci of the $\mathrm{L}_{1}$ and $L_{2}$ testers (Parents). When the dominance component is non-significant, an additive component free of the dominance contamination is estimated irrespective of the number of loci by which $\mathrm{L}_{1}$ and $\mathrm{L}_{2}$ differ (Mather and Jinks, 1971). For the traits with significant mean squares of sums and differences both additive and dominance components were involved in their genetic control. Therefore, hybridization breeding and selection in segregating generation are recommended for their improvement. As the estimate of $\mathrm{D}$ was higher than $\mathrm{H}$ for all the characters, hence, the degree of dominance was less than unity indicating the existence of incomplete and partial dominance except mucilage where over dominance was observed (Table 4). These results were in agreement with Panda and Singh (2000), Saravanan et al., (2005) and Mallikarjun et al., (2017).

Correlation of sums and difference (r) was non-significant for all the traits except fruit length and harvest duration, suggesting ambidirectional dominance (increasing and decreasing alleles) were more or less equally distributed among the genotypes.

Also, line $\times$ tester analysis was carried out as per the method given by Kempthorne (1957) after excluding the $\mathrm{L}_{3 \mathrm{i}}$ families and the $\mathrm{F}_{1}$ tester which revealed additive and dominance variance for different traits (Table 4). Comparison of the line $\mathrm{x}$ tester and triple test cross approach (Table 5) revealed that, in general, both additive and dominance genetic components have been underestimated in the line $\mathrm{x}$ tester mating design.

The underestimation for additive genetic component was to the extent of $-67.14 \%$ to $98.15 \%$ and dominant genetic component was underestimated in the range of $-84.34 \%$ to $88.12 \%$.

The Expected Mean Squares (EMS) of the sums and differences are as follows:

\begin{tabular}{|l|l|l|}
\hline Sov & DF & EMS \\
\hline Sums & & \\
\hline $\mathbf{L}_{\mathbf{i}}+\mathbf{L}_{2 \mathbf{i}}$ & $\mathrm{n}-1$ & $\delta^{2}+\mathbf{2} \mathbf{r} \delta^{2}$ sum \\
\hline Error & $(\mathrm{n}-1)(\mathrm{r}-1)$ & $\delta^{2}$ \\
\hline Differences & & \\
\hline $\mathbf{L}_{1 \mathbf{i}}+\mathbf{L}_{2 \mathbf{i}}$ & $\mathrm{n}-1$ & $\delta^{2}+\mathbf{2 r}, \delta^{2}$ difference \\
\hline Error & $(\mathrm{n}-1)(\mathrm{r}-\mathrm{l})$ & $\delta^{2}$ \\
\hline
\end{tabular}


Table.1 Analysis of variance showing mean squares for testing epistasis

\begin{tabular}{|c|c|c|c|c|c|c|c|c|c|}
\hline Source of variation & Replication & Treatment & Parent & Line & Tester & $\begin{array}{l}\text { Line vs } \\
\text { Tester }\end{array}$ & Hybrid & $\begin{array}{l}\text { Parent vs } \\
\text { Hybrid }\end{array}$ & Error \\
\hline Traits df & 2 & 50 & 14 & 11 & 2 & 1 & 35 & 1 & 100 \\
\hline $\begin{array}{l}\text { Days to } 50 \text { per cent } \\
\text { flowering }\end{array}$ & 1.48 & $57.53^{*}$ & $\begin{array}{c}136.58 \\
*\end{array}$ & $147.56^{*}$ & $26.38^{*}$ & $236.26^{*}$ & $19.44^{*}$ & $284.08 *$ & 1.84 \\
\hline Days to first picking & 3.26 & $31.67^{*}$ & $67.71 *$ & $75.06^{*}$ & 4.33 & $113.61 *$ & $12.31 *$ & $204.75 *$ & 2.79 \\
\hline First fruit producing node & 0.001 & $2.85^{*}$ & $3.01 *$ & $3.61 *$ & $1.24 *$ & 0.02 & $2.84^{*}$ & 1.06 & 0.27 \\
\hline Nodes per plant & 0.18 & $32.61^{*}$ & $69.82 *$ & $21.72 *$ & 11.08 & $716.40 *$ & $18.16^{*}$ & 17.53 & 8.90 \\
\hline Internodal length (cm) & 0.20 & $11.53^{*}$ & $15.08 *$ & $14.94 *$ & $19.95^{*}$ & $6.86^{*}$ & $10.39 *$ & 1.83 & 1.72 \\
\hline Fruit length (cm) & 0.03 & $1.61 *$ & $2.87^{*}$ & $3.18 *$ & $2.56^{*}$ & 0.001 & $1.15^{*}$ & 0.21 & 0.46 \\
\hline Fruit diameter (cm) & 0.02 & 0.09 & 0.19 & 0.17 & 0.17 & 0.37 & 0.04 & 0.45 & 0.14 \\
\hline Average fruit weight (g) & 0.53 & $10.81^{*}$ & 8.15 & 9.06 & 0.23 & 13.98 & $10.68^{*}$ & $52.54 *$ & 6.26 \\
\hline Plant height (cm) & 9.35 & $5182.32 *$ & $\begin{array}{c}8747.1 \\
4 *\end{array}$ & $3864.61 *$ & $18417.16^{*}$ & $43114.90^{*}$ & $\begin{array}{c}3768.28 \\
*\end{array}$ & $4766.19^{*}$ & 51.00 \\
\hline Harvest duration (days) & 0.48 & $16.37^{*}$ & $21.71 *$ & $17.07 *$ & 2.40 & $111.39 *$ & $14.61 *$ & 2.98 & 2.57 \\
\hline Fruits per plant & 0.33 & $28.18^{*}$ & $57.19 *$ & $17.98^{*}$ & 5.71 & $591.51 *$ & $16.74 *$ & 22.44 & 9.06 \\
\hline Fruit yield per plant (g) & 2.70 & $9289.83 *$ & $\begin{array}{c}14942 . \\
16 *\end{array}$ & $2586.46^{*}$ & $1963.51 *$ & $176812.14^{*}$ & $\begin{array}{c}6471.53 \\
*\end{array}$ & $28797.88^{*}$ & 15.86 \\
\hline Ridges per fruit & 0.15 & $2.44 *$ & $6.83^{*}$ & $8.54 *$ & $0.15^{*}$ & $1.37 *$ & $0.53 *$ & $7.76^{*}$ & 0.04 \\
\hline Dry matter (\%) & 0.02 & $2.07 *$ & $3.24 *$ & $2.67 *$ & $1.21 *$ & $13.61 *$ & $1.61 *$ & 1.44 & 0.40 \\
\hline Mucilage (\%) & 0.001 & $0.47 *$ & $0.22 *$ & $0.21 *$ & $0.10 *$ & $0.56^{*}$ & $0.53 *$ & $2.06^{*}$ & 0.001 \\
\hline
\end{tabular}

*Significant at $\mathrm{P} \leq 0.05$ 
Table.2 Analysis of variance for the detection of epistasis for fruit yield and horticultural traits

\begin{tabular}{|c|c|c|c|c|c|c|}
\hline Source of variation & Epistasis & $\begin{array}{c}\text { i-type } \\
\text { interaction }\end{array}$ & $\begin{array}{c}(\mathbf{j}+\mathbf{l}) \text { type } \\
\text { interaction }\end{array}$ & $\begin{array}{l}\text { Epistasis } x \\
\text { replication }\end{array}$ & $\begin{array}{c}\text { i-type } x \\
\text { replication }\end{array}$ & $\begin{array}{l}(j+1) \text { type } x \\
\text { replication }\end{array}$ \\
\hline Traits df & 12 & 1 & 11 & 24 & 2 & 22 \\
\hline $\begin{array}{l}\text { Days to } 50 \text { per cent } \\
\text { flowering }\end{array}$ & $73.74^{*}$ & 71.97 & $73.90^{*}$ & 12.10 & 24.65 & 10.96 \\
\hline Days to first picking & 35.25 & 30.25 & $35.71 *$ & 17.17 & 33.58 & 15.67 \\
\hline First fruit producing node & 3.19 & 3.15 & 3.20 & 2.49 & 0.88 & 2.64 \\
\hline Nodes per plant & 67.92 & 249.64 & 51.40 & 87.32 & 22.91 & 93.18 \\
\hline Internodal length $(\mathrm{cm})$ & 23.80 & 37.29 & 22.57 & 15.55 & 8.31 & 16.21 \\
\hline Fruit length $(\mathrm{cm})$ & 2.97 & $20.04 *$ & 1.42 & 3.19 & 0.55 & 3.42 \\
\hline Fruit diameter $(\mathrm{cm})$ & 0.03 & 0.17 & 0.02 & 1.20 & 0.10 & 1.30 \\
\hline Average fruit weight (g) & 70.23 & 208.90 & 57.62 & 66.98 & 27.18 & 70.60 \\
\hline Plant height (cm) & $3604.25^{*}$ & 1059.72 & $3835.57 *$ & 396.28 & 141.30 & 419.46 \\
\hline Harvest duration (days) & $56.43^{*}$ & $61.18^{*}$ & $56.00 *$ & 17.69 & 1.00 & 19.21 \\
\hline Fruits per plant & 58.80 & 291.04 & 37.69 & 91.11 & 37.47 & 95.98 \\
\hline Fruit yield per plant (g) & $18854.81 *$ & $990.88 *$ & $20478.81^{*}$ & 159.20 & 33.18 & 170.66 \\
\hline Ridges per fruit & 0.45 & $1.09 *$ & 0.39 & 0.28 & 0.03 & 0.30 \\
\hline Dry matter (\%) & 0.69 & 0.01 & 0.75 & 4.02 & 0.66 & 4.32 \\
\hline Mucilage (\%) & $4.11 *$ & $18.75^{*}$ & $2.78 *$ & 0.00 & 0.00 & 0.00 \\
\hline
\end{tabular}

*Significant at $\mathrm{P} \leq 0.05$ 
Table.3 Analysis of variance for sums $\left(\mathrm{L}_{1 \mathrm{i}}+\mathrm{L}_{2 \mathrm{i}}+\mathrm{L}_{3 \mathrm{i}}\right)$ and differences $\left(\mathrm{L}_{1 \mathrm{i}}-\mathrm{L}_{2 \mathrm{i}}\right)$ for fruit yield and horticultural traits

\begin{tabular}{|c|c|c|c|c|}
\hline \multicolumn{5}{|c|}{ Mean squares due to } \\
\hline Source of variation & Sums & Sums x Rep. & Differences & Diff. x Rep. \\
\hline Traits df & 11 & 22 & 11 & 22 \\
\hline Days to 50 per cent flowering & $73.21 *$ & 3.39 & $14.21 *$ & 4.60 \\
\hline Days to first picking & $44.43 *$ & 5.80 & 12.80 & 6.08 \\
\hline First fruit producing node & $7.97 *$ & 0.59 & $2.65^{*}$ & 0.60 \\
\hline Nodes per plant & 41.80 & 20.88 & 14.19 & 18.75 \\
\hline Internodal length $(\mathrm{cm})$ & $33.70 *$ & 3.41 & 7.93 & 4.19 \\
\hline Fruit length (cm) & $2.81 *$ & 1.10 & 0.90 & 0.84 \\
\hline Fruit diameter $(\mathbf{c m})$ & 0.06 & 0.30 & 0.02 & 0.29 \\
\hline Average fruit weight (g) & $33.72 *$ & 10.29 & 15.88 & 11.25 \\
\hline Plant height $(\mathrm{cm})$ & $6391.82^{*}$ & 110.98 & $1443.71 *$ & 97.04 \\
\hline Harvest duration (days) & $31.59^{*}$ & 7.95 & $15.30 *$ & 5.26 \\
\hline Fruits per plant & 37.69 & 18.84 & 12.17 & 17.05 \\
\hline Fruit yield per plant (g) & $22497.73^{*}$ & 56.96 & $5438.12 *$ & 27.28 \\
\hline Ridges per fruit & $1.98^{*}$ & 0.11 & $0.42 *$ & 0.09 \\
\hline Dry matter (\%) & $5.85^{*}$ & 0.66 & 0.27 & 1.02 \\
\hline Mucilage (\%) & $0.76^{*}$ & 0.00 & $0.91^{*}$ & 0.00 \\
\hline
\end{tabular}

*Significant at $\mathrm{P} \leq 0.05$

Table.4 Additive and dominance variance as revealed by triple test cross and line $\mathrm{x}$ tester analysis

\begin{tabular}{|c|c|c|c|c|c|c|c|}
\hline \multirow[t]{3}{*}{ Trait } & \multicolumn{7}{|c|}{ Estimates of genetic parameters } \\
\hline & \multicolumn{3}{|c|}{ Triple Test Cross } & & \multicolumn{3}{|c|}{ Line $x$ Tester } \\
\hline & D & $\mathbf{H}$ & $(H / D)^{1 / 2}$ & $\mathbf{r}$ & $\sigma^{2} A$ & $\sigma^{2} D$ & $(\mathrm{D} / \mathrm{A})^{1 / 2}$ \\
\hline Days to 50 per cent flowering & $93.10 *$ & $12.81 *$ & 0.37 & -0.04 & 4.70 & 1.75 & 0.61 \\
\hline Days to first picking & $51.52 *$ & 8.95 & 0.42 & -0.27 & 2.94 & 1.19 & 0.64 \\
\hline First fruit producing node & $9.83^{*}$ & $2.73 *$ & 0.53 & -0.70 & 0.19 & 0.35 & 1.35 \\
\hline Nodes per plant & 27.89 & - & - & -0.23 & 4.03 & - & - \\
\hline Internodal length $(\mathrm{cm})$ & $40.40 *$ & 4.98 & 0.35 & 0.04 & 3.58 & 0.78 & 0.47 \\
\hline Fruit length $(\mathrm{cm})$ & $2.28^{*}$ & 0.08 & 0.19 & $0.64 *$ & 0.33 & - & - \\
\hline Fruit diameter $(\mathrm{cm})$ & - & - & - & 0.15 & 0.03 & - & - \\
\hline Average fruit weight (g) & $31.23 *$ & 6.16 & 0.44 & 0.04 & 1.15 & 0.90 & 0.88 \\
\hline Plant height (cm) & $8374.46 *$ & $1795.57 *$ & 0.46 & 0.35 & 2751.62 & 223.26 & 0.28 \\
\hline Harvest duration (days) & $31.52 *$ & $13.38^{*}$ & 0.65 & $0.68^{*}$ & 1.60 & 1.59 & 1.00 \\
\hline Fruits per plant & 25.13 & - & - & 0.29 & 2.50 & - & - \\
\hline Fruit yield per plant (g) & 29921.03* & $7214.46^{*}$ & 0.49 & 0.00 & 554.44 & 901.26 & 1.27 \\
\hline Ridges per fruit & $2.50^{*}$ & $0.44^{*}$ & 0.42 & 0.43 & 0.05 & 0.06 & 1.09 \\
\hline Dry matter $(\%)$ & $6.92 *$ & - & - & -0.63 & 0.16 & - & - \\
\hline Mucilage (\%) & $1.01 *$ & $1.21 *$ & 1.10 & -0.09 & 0.02 & 0.15 & 2.56 \\
\hline
\end{tabular}

*Significant at $\mathrm{P} \leq 0.05$

$(\mathrm{H} / \mathrm{D})^{1 / 2}=$ Degree of dominance

$\mathrm{D}=$ Additive component, $\mathrm{r}=$ Correlation

$\mathrm{H}=$ Dominance component, - = Not calculated (because of negative value) 
Table.5 Comparison of TTC and line $\mathrm{x}$ tester analysis in the estimation of additive and dominance genetic component

\begin{tabular}{|l|c|c|}
\hline Trait & D & H \\
\hline Days to 50 per cent flowering & -94.95 & -86.34 \\
\hline Days to first picking & -94.29 & -86.70 \\
\hline First fruit producing node & -98.07 & -87.18 \\
\hline Nodes per plant & -85.55 & - \\
\hline Internodal length (cm) & -91.14 & -84.34 \\
\hline Fruit length (cm) & -85.53 & - \\
\hline Fruit diameter (cm) & - & - \\
\hline Average fruit weight (g) & -96.32 & -85.39 \\
\hline Plant height (cm) & -67.14 & -87.57 \\
\hline Harvest duration (days) & -94.92 & -88.12 \\
\hline Fruits per plant & -90.05 & - \\
\hline Fruit yield per plant (g) & -98.15 & -87.51 \\
\hline Ridges per fruit & -98.00 & -86.36 \\
\hline Dry matter (\%) & -97.69 & - \\
\hline Mucilage (\%) & -98.02 & -87.60 \\
\hline - Not calculated (because of negative value) & & \\
\hline
\end{tabular}

In general, the underestimation was comparatively more with respect to additive genetic variance in relation to dominance variance except for the plant height. Pooni and Jinks (1976) have also reported that for getting the precise information on the additive genetic variance even in the presence of epistasis, the TTC is most powerful.

Since epistasis was detected for most of the traits including fruit yield, it is hereby inferred that estimation of genetic components of variation by models assuming absence of epistasis would be significantly biased and can cause consequent bias in estimates of heritability and other genetic parameters.

However, as of now, there is no conclusive evidence about the extent of bias and the effect of epistasis on the expression of quantitative traits. Studies for assessment of relative importance of epistatic component need to be carried out by developing appropriate genetic models. Overall, for the inheritance of different characters the triple test cross revealed the importance of additive, dominance and epistasis gene actions.

The kind of genetic variance revealed from triple test cross can be exploited by intermating selected individuals in early segregating generations with delayed selection in later generations, diallel selective mating/ biparental mating or recurrent selection followed by pedigree method to exploit both additive and non-additive components along with epistasis. Triple test cross analysis was found more powerful in estimating additive and dominance genetic variance as compared to line $\mathrm{x}$ tester approach even in the presence of epistasis.

\section{Acknowledgement(s)}

The author is highly grateful to Dr. Sonia Sood (Professor) for her help during the course of investigation. 


\section{References}

Anonymous. 2018. Area and Production Statistics. National Horticulture Board, Gurgaon, New Delhi.

Arora, D. and Ghai, T.R. 2007. Estimation of genetic components using triple test cross analysis in inter-varietal crosses of okra. Journal of Research Punjab Agricultural University. 44 (1): 55-58.

Arora, D., S.K. Jindal, T.R. Ghai and Singh, K. 2007. Estimation of epistasis in intervarietal crosses of okra. Vegetable Science. 34 (2): 181-184.

Cockerham, C. C. 1961. Implications of genetic variances in a hybrid breeding programme. Crop Sci. 1: 47-52.

Comstock, R.E. and Robinson, H.F. 1952. Estimates of average dominance of genes. In: JW Gowen ed. Heterosis. Lowa State College Press, lowa, pp 494-516.

Comstock, R.E., and Robinson, H.F. 1948. The components of genetic variance in population of biparental progenies and their use in estimating average degree of dominance. Biometrics. 4: 254-266.

Hayman, B.I. 1954. The theory and analysis of diallele crosses. Genetics. 39: 789809.

Jinks, J.L. and Perkins, J.M. 1970. A general method for the detection of additive, dominance and epistatic components and variation III $\mathrm{F}_{2}$ and backcross populations. Heredity. 25: 419-429.

Kearsey, M. and H.S. Pooni. 1998. The Genetical Analysis of Quantitative Traits. Chapman and Hall, UK.

Kearsey, M.J. and Jinks, J.L. 1968. A general method for detecting additive, dominance and epistatic variation for metrical traits. Heredity. 23: 403-409.

Kempthorne, O. 1957. An introduction to genetic statistics. John Wiley and Sons Inc., New York.
Mallikarjun, K., E. Ganagappa, L.V. Kumar, T. Basavaraja and Ramesh, S. 2017. Determination of genetic components through triple test crosses in okra [Abelmoschus esculentus (L.) Moench]. Journal of Current Microbiology and Applied Sciences. 6 (9): 1991-1999.

Mather, K. and J.L. Jinks, 1982. Biometrical Genetics. $3^{\text {rd }}$ Edn. Chapman and Hall, London.

Mather, K. and J.L. Jinks. 1971. Biometrical genetics. $2^{\text {nd }}$ Edn. Chapman and Hall, London.

Mather, K. and Vines, A. 1952. The inheritance of height and flowering time in a cross of Nicotiana rustica. Quantitative Inheritance. pp. 45-80.

Opsal, B. 1956. The discrimination of interactions and linkage in continuous variation. Biometrics. 12: 415-432.

Panda, P.K. and Singh, K.P. 2000. Modified triple test cross analysis for yield and yield components in okra (Abelmoschus esculentus (L.) Moench). Indian Journal of Genetics. 60: 569-571.

Pooni, H.S. and Jinks, J.L. 1976. The efficiency and optimal size of triple test cross designs for detecting epistatic variation. Heredity (Edinb). 36(2): 21527.

Pooni, H.S., Kumar, I. and G.S. Khush, 1994. A general method of the detecting additive, dominance and epistatic variation for metrical traits. V. Triple test cross analysis of disomically inherited traits expressed in triploid tissues. Heredity. 72: 563-569.

Saravanan, K., T. Sabesan, N. Senthil Kumar and Ganesan, J. 2005. Triple test cross analysis in bhendi (Abelmoschus esculentus (L) Moench). Indian Journal of Agricultural Research. 39: 242-248.

Singh, BB, Singh, UP, Singh, RM and Rai, B. 1987. Genetic analysis of yield and yield components in field peas. Journal of Agricultural Sciences. 109: 67-71. 
Singh, S. and Singh, R.B. 1976. Triple test cross analysis in two wheat crosses. Heredity. 37: 173-177.

Tripathi, V. and Arora, S.K. 2001. Detection of epistasis and components of genetic variation in okra (Abelmoschus esculentus (L.) Moench). Vegetable Science. 28: 109-112.

\section{How to cite this article:}

Akhilesh Singh, Sonia Sood and Sood, V.K. 2019. Detection of Epistasis and Estimation of Additive and Dominance Components of Genetic Variation for Fruit Yield and Horticultural Traits in Okra [Abelmoschus esculentus (L.) Moench]. Int.J.Curr.Microbiol.App.Sci. 8(07): 747-756. doi: https://doi.org/10.20546/ijcmas.2019.807.090 